\title{
Bounded Rationality, Capital Budgeting Decisions and Small
}

\section{Business.}

\begin{abstract}
Purpose - The purpose of our paper is to give insight into the capital budgeting decisionmaking of Canadian and Mexican entrepreneurs in small businesses in the food sector. The objective is to understand the capital budgeting decisions through the lens of bounded rationality and how these decisions are affected by different (national) contexts. Design/methodology/approach - The use of Constructivist Grounded Theory allowed deep conversations about the capital budgeting decisions. Data was collected from forty semistructured interviews with entrepreneurs/managers in two regions, Mexico and Canada. Findings - Insights from this study confirm that entrepreneurs' capital budgeting decisions are taken under conditions of bounded rationality, but also suggest the prominent role of context in how bounded rationality is used.

Research limitation/implications - Because of the exploratory nature of this study, insights from this research cannot be generalized. However, by exploring the entrepreneur's decisions, in these specific regions and sector, the insights of this study are relevant to these entrepreneurs and they can help to improve their decisions.

Practical implications - Using a bounded rationality lens, this study contrasts and explains similarities and differences in the entrepreneur's capital budgeting decisions-making in two regional contexts. It also suggests the prominent influence of context when taking capital budgeting decisions.

Originality/value - The paper uses constructivist grounded theory to explore entrepreneurs' capital budgeting decision-making, in the small business, in two regions, Canada and Mexico.
\end{abstract}

\section{Keyword}

Decision-making, capital budgeting, small business, comparative study, regional, Mexico, Canada, entrepreneurship, context by Emerald. The original publication is available at https://doi.org/10.1108/QRAM-01-2019-0020. This article is deposited under the Creative Commons Attribution Non-commercial In allowed in accordance with the terms outlined by the licence (https://creativecommons.org/licenses/by-nc/4.0/). To reuse the AAM for commercial purposes, permission should be sought by contacting permissions@emeraldinsight.com. 


\section{Introduction}

Entrepreneurial activity is prominently linked to economic growth (Acs et al., 2009; Leigh and Blakely, 2013; Szirmai et al., 2011; Schumpeter, 1961) and entrepreneurs are hence attributed an important role in today's economies. This equally applies to the regional contexts of this study, Canada and Mexico. Despite their important societal role, entrepreneurs often operate under financial constraints (Carter and Van Auken, 2005; Braggion et al., 2018) while the role of financial resources has long been identified as central to entrepreneurial activity and small business (Holtz-Eakin et al., 1994; Beck and DemirgucKunt, 2006; Muller and Zimmermann, 2009). In this paper, we shed additional light on capital budgeting decision-making which is seen to play an important role for firms' longterm performance (Swain and Haka, 2000; Kim, 1981).

According to mainstream US managerial accounting and financial management literature, capital budgeting decision makers should use financial techniques and decide on the capital investment alternative that maximizes the firm's value (Bierman Jr and Smidt, 2012; Garrison et al., 2018). Capital budgeting techniques suggest the application of mathematical models and presume rational decisions being made, but this is not always the case, particularly in smaller firms without or with little adherence to formal capital budgeting techniques (Andor et al., 2015). The observation that extant capital budgeting research seems over reliant on financial appraisal tools (Alkaraan and Northcott, 2006; Phelan, 1997), then suggests a need to more systematically consider external influences ( $M a$ and Tayles, 2011) and appreciate the complexity of real-life situations more strongly (Emmanuel et al., 2010).

Early seminal research on decision-making suggests that decision makers simplify the complexity of problems and reduce the direct cost of decision-making by following some "rules of thumb" in the absence of more comprehensive information (Simon, 1976). More recent research still suggests that decision makers do not always follow a rational model (Northcott, 1991) and that capital appraisals often follows a "simple is best" philosophy (Alkaraan and Northcott, 2006; Carneiro Lima et al., 2017). While the simplification might appear reasonable as decision makers are unlikely to hold all relevant information they need to anticipate all the outcomes (Alkaraan and Northcott, 2006), simplifying the decision process poses a problem if the overall cost of suboptimal decisions outweighs the reduced decision-making costs.

This paper focus on the individual and aim to provide insight on how individual decision makers in small business contexts decide between different capital investments alternatives. Accepting an absence (or impossibility to gain) complete information, how do small business owners search for capital investment alternatives? When do they stop searching? How do they satisfy the capital investment decision? What are the common patterns -if any- in the entrepreneurs' capital budgeting decision- making? Are these patterns consistent across regional contexts and if (or also if not) what might explain these patterns? These are questions directly associated with the problem of the mode of decision-making and the cost involved and will be addressed in the remainder of this paper.

Employing a qualitative research approach and empirically set in the food sector, this paper intends to gain insights into the capital budgeting decision-making process in small 
businesses in two different regional contexts, Canada and Mexico. Our insights are argued to be of value for the field of managerial accounting and entrepreneurship by exploring capital budgeting decision-making through the lens of bounded rationality at the individual level, and adding to our understanding about the role of regional context (Carr et al., 2010; Carr and Harris, 2004; Emmanuel et al., 2010). Reflecting on the current scholarly debates on bounded rationality with special consideration of capital budgeting, this paper substantiates the relevance and anticipated contribution of our study. Our paper then proceeds to introduce the study's research design, illustrates key insights and concludes with a discussion, limitations and practical contributions.

\section{Literature review}

For many years, scholars from different disciplines have been trying to understand how individuals and organizations make decisions. Scholars agree that decision-making involves "selecting among possible actions" (Gilhooly, 1988) and that understanding how decisions over capital investments are made is of high relevance to management and accounting practitioners and also management accounting researchers (Harris et al., 2016). However, conventional notions of decision-making have neglected key human faculties and individual characteristics (Alkaraan and Northcott, 2013). Potential gaps in our knowledge and avenues for gaining additional insights on the role of rationality in capital budgeting literature are identified below.

\section{Bounded rationality and decision-making in small businesses}

The individual decision maker plays a central role as creator, actor, carrier, and is often driven by the forces of affect, insight and inspiration (Langley et al., 1995). The nexus of entrepreneurship and decision-making appears to be well researched. For instance, scholars suggest that entrepreneurial decision-making is affected by the level of education, training, experience, and skills (Davidsson and Honig, 2003); the perception of the environment (McKelvie et al., 2011); gender (Powell and Greenhaus, 2010; Langowitz and Minniti, 2007); national cultural heritage (Holt, 1997); planning (Chwolka and Raith, 2012); underlying business plans (Delmar and Shane, 2003); family involvement (Vincent, 1996) and industry conditions (Levesque et al., 2009), among others.

Entrepreneurs take decisions in real time, often with no previous historical background on that particular matter or previous results, and in many cases decision makers do not have adequate time to prepare a plan (Northcott, 1991; Saukkonen et al., 2018). As a result, decision makers take their decisions under a condition of uncertainty (Verbeeten, 2006; Elmassri et al., 2016; Harris, 2014; Graham and Sathye, 2017). In this scenario, intuition (Elbanna and Fadol, 2016), judgement (Emmanuel et al., 2010), biases (Kahneman et al., 1982) and heuristics (Gigerenzer, 2008) can guide decisions, especially when more cautious and comprehensive decision-making is not possible (Busenitz and Barney, 1997).

There is ample evidence suggesting that entrepreneurs rely on bias and heuristics when taking decisions (Shepherd et al., 2014). Past research supports assumptions that entrepreneurs over generalize using limited information (Busenitz and Barney, 1997; Forbes, 2005; Simon et al., 2000), give preferences to previously chosen alternatives (Burmeister and Schade, 2007), and rely on their own competency while neglecting (yet not actively ignoring) 
the environment they are embedded in (Moore et al., 2007). More recently Carneiro Lima et al. (2017) suggest to move beyond the traditional economic rationality lens intrinsic to capital budgeting techniques and follow considerations of managerial bounded rationality.

The theory of bounded rationality (Simon, 1955) incorporates such caveats and sees decision-making subject to the cognitive limitations of the individual, the complexity of the environment, the tendency to set aspiration levels for each goal the individual or organization has and the tendency to operate on a goal sequentially, satisficing rather than optimizing (Jones, 1999). The theory suggests two sets of bounds: a) external, which refers to the cost of searching for the information, and b) internal, which refers to the limited cognitive ability to process the information (Simon, 1981). In addition, bounded rationality is associated with two central concepts, search and satisficing (Simon, 1979). For search, Simon (1979: 502) states that "if choices are not given initially to the decision maker, then, he must search for them"; for satisficing, Simon (1979: 503) states that "as soon as he discovered an alternative for choice that meets his level of aspiration, he would terminate the search and choose that alternative".

Simon's initial ideas have evolved over the past few decades. In a deconstruction of the interpretation of bounded rationality over time, (Petracca, 2017) suggests to distinguish a wider version ( Simon $_{1}$; the scissors version with the two blades of contextual characteristics and individual cognition adopting to this context) and a narrower version (Simon 2 ; merely containing one blade, the individual cognition and its limitations). While the second version has found acceptance in the economics literature, it could be argued that this later adopted lens has silenced the "real revolutionary nucleus of Simon" (Petracca, 2017: 22); referring to the complementarily between context and cognitive abilities. This is also reflected in how Simon's work is adopted and advanced by others. Bounded rationality could focus on (a) optimization under constraint or (b) cognitive limitations or (c) an ecological rationality (Todd and Gigerenzer, 2003).

The view of bounded rationality mainly as a cognitive illusion (Simon 2 ) is a base of behavioural economics. It suggests a number of cognitive biases such as: base rate neglect, overconfidence bias, and the sunk-cost effect (Tversky and Kahneman, 1974). Others, for instance, Gigerenzer and Selten (2001), argue in Simon ${ }_{1}$-fashion that bounded rationality can be seen as ecological rationality, which considers the internal limitations of the (human) mind and also the structure of the external environments in which the mind operates (Todd and Gigerenzer, 2003). The latter is the perspective that this paper follows. Our research hence responds to the call for more consideration of context in research on management (Galvin, 2014) and strategic decision-making (Papadakis et al., 1998; Carr and Harris, 2004).

\section{Capital budgeting decision-making}

Following the suggestion that the success of small businesses, to a large extent, depends upon the strategic investment decision-making practices (Robinson Jr and Pearce, 1983), the entrepreneur's decisions can be considered essential for both, firm performance and economic development. Additionally, capital budgeting represents an important ingredient in the firm's managerial accounting decisions (Garrison et al., 2018; Verbeeten, 2006) and in the long term performance (Northcott, 1991; Emmanuel et al., 2010; Swain and Haka, 2000). 
Ross et al. (2016: 2) define capital budgeting as "how to plan and manage the firm's investment in long-term assets". Capital investment requires a significant amount of financial resources (Chittenden and Derregia, 2015). They are made in hope of generating higher cash flows over a reasonably long period of time in the future. They play a key role in the firm's strategic decisions, e.g. expansion, equipment replacement, new equipment selection, cost-reduction, and the option to lease or buy (Garrison et al., 2018). Because of the relevance of these decisions, managerial accounting theory offers a set of techniques as a decision-making framework to analyse the investment alternatives (Garrison et al., 2018).

There is a plethora of studies on which/how capital budgeting techniques are used (Alkaraan and Northcott, 2006; Pike and Wolfe, 1988; Arnold and Hatzopoulos, 2000; Ho and Pike, 1991; Lefley, 1994), management accountants and financiers have developed a variety of capital budgeting techniques for project ranking and evaluation that includes, payback, average accounting return, discounted payback, internal rate of return, and profitability index, among others (Garrison et al., 2018; Ross et al., 2016). In addition, much of the research on capital budgeting techniques is associated with larger firms (Block, 2007; Ryan and Ryan, 2002; Liljeblom and Vaihekoski, 2004; Alkaraan and Northcott, 2006; Huikku, 2008; Huikku et al., 2018), and less with small businesses (Block, 1997; Lazaridis, 2004; Bellouma, 2010; Hamid et al., 2011; Ben-Caleb et al., 2013; Harada and Honjo, 2005). However, capital budgeting decisions, particularly in relation to entrepreneurs/smaller businesses remain under-researched - despite their increasingly acknowledged importance (Roberts and Gnan, 2017).

\section{Past research shows that capital budgeting decision-making has been dominated by quantitative analyses (Harris et al., 2016). With findings not entirely consistent (Pike, 1996; Arnold and Hatzopoulos, 2000), more subjective insights on decision-making approaches for capital budgeting practices and qualitative perspectives emerged (Butler et al., 1991; Alkaraan and Northcott, 2006; Emmanuel et al., 2010). Recently, Elmassri et al. (2016) argue that in practice often non-financial considerations and objectives prevail over the suggested accounting capital investment techniques. This insight suggests that decision makers simplify the complexity of strategic investment decisions (Shepherd et al., 2014). Simplifying capital investment appraisal has been explored through the role of experience, intuition (Alkaraan and Northcott, 2006; Alkaraan and Northcott, 2013; Alkaraan, 2016) and judgement (Alkaraan and Northcott, 2006; Harris et al., 2009), yet, studies that link bounded rationality and the individual entrepreneur's capital budgeting decisions remain scarce.}

\footnotetext{
Aligned with past research rendering bounded rationality as a prominent phenomenon illustrating decision-making in entrepreneurial and small business settings, heuristics is seen as a superior strategy when testing entrepreneurial conjectures (Shepherd et al., 2012) and in relation to capital budgeting decisions. As an example, research has found that entrepreneurs vary with respect to the level of optimism they have when making decisions. For instance, nascent entrepreneurs are (more) optimistic with their sales projections (Cassar, 2010) and show more optimism in their valuation and projections for their investments (Dushnitsky, 2010). Some scholars suggest that this optimism seems to result from the need to enhance self-esteem (Parker, 2009). Similar optimism was found to be present in the preparation of plans and financial projections (Cassar, 2010) and might be
} 
seen as an underlying reason for delaying decisions to terminate unsuccessful projects (Lowe and Ziedonis, 2006).

\section{Gap in the literature}

This article seeks to contribute in different ways to the literature: although the nexus of bounded rationality and the individual-entrepreneur decision-making has been explored (Palich and Bagby, 1995; Busenitz and Barney, 1997; Burmeister and Schade, 2007), as far as our knowledge goes, there is very little academic work that links bounded rationality with an individual's capital budgeting decisions (Kingsley and Reed, 1991; Emmanuel et al., 2011; Pike, 1996). Additionally, this research departs from traditional small business and capital budgeting research using questionnaire surveys in a positivist, quantitative tradition (Gartner and Birley, 2002; Burns and Walker, 2009; Drury and Tayles, 1996). Instead, this study is based on semi-structured interviews, taking a constructivist lens, and pursuing a qualitative approach. This study is not debating that a constructivist perspective is the better way to research capital budgeting in smaller firms per se, but agrees with Bruyat and Julien (2001) that constructivism and positivism could co-exist in entrepreneurship and small business research as they do in the field of strategic management (Porter, 1991; Schendel, 1994) and could even complement each other. Furthermore, this qualitative paper is in line with a more recently found openness within the scholarly community regarding nonpositivist work published in top-tier journals (Corley, 2011; Baker, 2014).

Extant research has already shed some light on the links of context with individual/entrepreneurial decision-making (McKelvie et al., 2011; Jackson, 2010; Bamford et al., 2000), A recent example is Harris et al, (2014) looking at the nexus of strategic investment decisions and social, economic, cultural and political influences in managerial judgement. Despite these advances in research, managerial accounting practice still seems to be dominated by technical approaches and fails to account for context or intuition (Harris, 2014; Emmanuel et al., 2010). This paper adds to extant works suggesting a shift from focussing capital budgeting research to strongly on techniques (Arnold and Hatzopoulos, 2000; Alkaraan and Northcott, 2006) and instead taking a more contextualized approach (Harris, 2014; Carr et al., 2010; Graham and Sathye, 2017), reflecting experiences of decision makers in real organizations settings Harris et al. (2016).

Two major contextual elements - which can be argued to have found considerably little attention in previous strategic investment or capital budgeting research are the size of companies (smaller entrepreneurial firms) and less main-stream regional contexts. This study considers the individual/entrepreneur in the small business as a central actor of the decisions and hence responds to Emmanuel et al. (2010), Kingsley and Reed (1991) and Pike's (1996), longstanding reservations that strategic investment decision and strategic management accounting research often ignore the role of the decision maker.

While there is academic work that links capital budgeting and small business (Chittenden and Derregia, 2015), most of the research has taken place in USA, UK, Europe and Africa, but very little in other regional context such as Latin America, for instance. Mexico and Canada are geographically close but separated by the USA. Canada and Mexico have different economies, culture, government, law, and institutional systems. These differences seem to 
present attractive contextual variation for comparing the entrepreneur's capital budgeting decision-making and exploring whether (and how) context might play a role in our understanding of bounded rationality (see our discussion on Simon 1 vs. Simon 2 above). This paper will posit that bounded rationality can be more comprehensively understood when context is considered.

\title{
Methodology
}

Earlier in this journal Carneiro Lima et al. (2017) suggests capital budgeting decision-making to be a complex theme and explicitly calls for more in-depth investigative approaches being adopted. This study collects qualitative data among entrepreneurs/small businesses in the food manufacturing industry in two regions: Peterborough and Northumberland counties in Ontario, Canada and in Merida, Yucatan, Mexico. Our insights presented in this study are based on data drawn from forty in-depth, semi-structured, open-ended, face-to-face interviews conducted in both locations at the entrepreneurs' business offices.

\begin{abstract}
This study is empirically located in the food sector. This industry selection seems beneficial for two reasons: First, the food processing industry is considered relevant to both regional economies in Merida and in central-eastern Ontario. According to Agriculture and Agri-Food Canada (2019), the food processing industry is the largest manufacturing industry in most provinces in Canada, with Ontario and Quebec accounting for most of the production. This industry invests about $\$ 2$ billion Canadian dollars annually in capital expenditures, with $80 \%$ of the total investment in machinery and equipment (Agricultural and Agri-Food Canada 2016). Also the Mexican food sector industry lends itself to further empirical study. The food sector industry employs $4 \%$ of the Mexican work force (with a growth of 20\% from 2004 to 2009) and its economic output represents 6.5\% of the Mexican economy (with a growth of 75\% from 2004-2009) (Mexico-Now, 2016). The Mexican food industry is the third biggest on the continent, trailing only the US and Brazil. Beyond its economic footprint, the food sector is particularly suitable for comparative research as this sector exists in most of the countries around the world, allowing for further research in other country contexts, as proposed by House et al. (2004) in the GLOBE study.
\end{abstract}

\section{A basic interview guide to access bounded rationality and entrepreneurial concepts (see} appendix A) was prepared, to create, revise and fine-tune the open-ended interview questions, inform when and how to make the interview questions (Charmaz, 2014), and to stimulate interactions between the researcher and participants. The interview questions were composed of two sections. In the first section, questions were related to the entrepreneurs' demographics, e.g. background experience, company size and company age. In the second section, questions were related to the entrepreneur's past capital budgeting decision experiences. In order to fully understand the entrepreneurs' experiences, the conversation iterated between entrepreneur and researcher. This process helped to adapt, expand, emphasize, clarify, and explore a little more different aspects of the conversation. During the interview, the researcher took observational field notes, interview notes, and audio digitally recorded the interview. After the interview, the researcher elaborated a "thick description" (Geertz, 1973) of the context where the interview took place (Qu and Dumay, 2011). Finally, the interviews were transcribed in their original languages, English and Spanish. 
Based on the exploratory aim of this research and on its epistemological and ontological considerations, constructivist grounded theory (Charmaz, 2014) seems to be a fit to this study. Constructivist grounded theory allowed to collect and analyse data and theorize based on the constant comparison between data. In addition, the constructivist lens helped to understand the entrepreneurs' realities constructed by them and the implications of these constructions for their lives and interactions with others (Patton, 2002). Constructivist grounded theory is located at the opposite end of the positivism approach to the initial format of grounded theory research (Glaser and Strauss, 1967). It actively repositions the researcher as the author of a reconstruction of experience and meaning.

The unit of analysis was the individual entrepreneur/founder/manager of the venture, the individual who could be identified as responsible for making the capital budgeting decisions within their organisation. This study used a criterion sampling strategy (Kemper et al., 2003). The selected sampling strategy was conceptually aligned with the research aim and the same time was seen as credible, feasible, ethical and efficient. The small businesses' names were extracted from their respective chambers of commerce. The selection process required screening these organizations based on product, location, and the organization's size based on the number of employees. Table 1 in the following chapter describes the participants' demographics in more detail.

During the data collection, the researcher observed the setting, interactions, witnessed research participants' non-verbal behaviour, and heard their voices (Charmaz, 2014). Two sets of Nvivo projects were created, one for the Mexican sample and another for the Canadian sample. The data reduction was possible using codes. In Nvivo, the coding process allowed the researcher to separate, group, regroup and link the data in order to facilitate identifying the meaning and interpretations (Grbich, 2012). The analysis started with the "initial coding", in which the researcher selected a word that constituted the code (Charmaz, 2014), the researcher used these codes to define what the researcher saw significant in the data, to describe what the researcher thought was happening (Charmaz, 2014: 115). These sets of codes were provisional, comparative and grounded in the data (Charmaz, 2014). During this coding process the researcher selected general terms from the interviews such as experiences and events, telling to the researcher more about the participant's meanings and actions (Charmaz, 2014: 120). The initial coding, line-by-line, allowed the researcher to be immersed in the data (Charmaz, 2014: 127). The second stage of the analysis was the "focus coding". In this stage, the researcher used the most frequent earlier coding to separate the large amount of data (Charmaz, 2014). Based on the "focus codes", the "theoretical coding" helped the researcher to conceptualize how the codes were related moving it to an analytical direction (Charmaz, 2014).

In order to address the trustworthiness, the researchers considered credibility, dependability, transferability and confirmability. To increase credibility, the researchers used well known theories in the conceptual framework, and properly described the research design, the data collection and analysis. Dependability was enhanced by the derivation of coding, the application of formalized stages of research (Charmaz, 2014), and an audit trail (Lincoln and Guba, 1985). Transferability was ensured by preparing "thick descriptions" (Geertz, 1973), the use of relevant literature (Simon, 1957; Ross et al., 2008), the use of criterions sampling (Patton, 2002), and conceptual equivalence (Sinkovics et al., 2008). 
Finally, confirmability was enhanced by letters of inform and letters of consent (Sinkovics et al., 2008), and by receiving ethic clearance (Sinkovics et al., 2008).

\section{Insights from the interviews}

As presented in the introduction section, our research aim is to enhance our understanding of the entrepreneur's capital budgeting decision-making through the lens of bounded rationality. This paper will address the research questions, both, for the case of Mexico and Canada. The insights were collected from a sample of entrepreneurs in both regional contexts which is illustrated in Table 1 below. By using the responses from the interviews, this study believes that it can contribute to our understanding of entrepreneurs' capital budgeting decision-making. In an attempt to answer the questions above, this study will attempt to identify the patterns -if any- of these types of decisions. Whether the patterns are consistent across regions and to what extent contextual differences become visible in capital budgeting decisions and how the "rule of thumb" is differently visible in these decisions.

$===$

Add Table 1 around here

$===$

\section{Capital budgeting in Mexico}

Regarding the question of how Mexican entrepreneurs search for capital budgeting alternatives, the interviews show that they use a variety of methods to inform their decisions. The most common method being the internet, industry magazines and contact with suppliers.

Mexican entrepreneurs used the internet and industry magazines to explore what capital investment alternatives are out there: types, origin, prices, purchase conditions, capacities, customer online reviews, etc. Mexican entrepreneurs are aware of well-known brand equipment that produce higher quality products and have a longer life, unfortunately for the entrepreneurs these equipments are above their financial possibilities (aspiration level), but they use these tools to learn about what is new and to get ideas.

...I believe that the Internet is a reality; a computer is a reality. I think a big difference with respect to my dad's generation is that my dad does not use computers, does not use cell phones, does not use anything in particular. Here, we have Internet, computer, cell phone. I do not go out to find information-M2.

One of the most common methods to search for capital investment alternatives is through suppliers. The suppliers provide the entrepreneur with information about what is new in the market, types of equipment, capacities, prices, requirements and in many cases, they share who else is using similar machinery. Suppliers could represent local, national or international brands.

...there are technicians [suppliers] who offer the services of a company and there are independent experts [suppliers] who say, well, say, if there is already a pack- 
aging here, they can do it in Yucatan, or we need to get somewhere in Mexico, or we had to get it abroad - M19.

Mexican entrepreneurs stop searching for alternatives when they satisfy their aspiration level. Based on the interviews, two consideration stands up for satisficing; financial considerations and trust, in other words, affordability and dealing with non-member family workers. Often, Mexican entrepreneurs reported facing financial difficulties, therefore the financial aspect more strongly dictated decisions. This is for instance suggested by M16 and M18 who "already had previous quotes for industrial machines, but those were in the millions and more" (M16) preventing a decision for a technologically more attractive solution and hence admitting that "everything is based on how much you can allocate to the purchase of the equipment" (M18).

\section{Non-family member labour cost is another consideration. Samples of these can be seen in M17, M2 and M9 comments that a decision "would be good if you really, if the equipment we buy really is going to replace handwork" (M17). M2 explicitly compared labour cost versus new equipment operating cost, arguing that he "must assess whether it is more profitable to use a machine or to use labour". In a similar logic M9 refers to labour cost reduction as an important factor when evaluating capital investment alternatives: "If the machinery reduces labour cost, definitely. Do you understand me? To replace workers." It seems important to note here that for all aspects related to reducing the labour cost, the aim was to reduce non-family member's workers.}

The interviews have illustrated entrepreneurs' lack of time, resources and knowledge, pushing them to such fast and frugal decisions without exploring all the possible alternatives. A possible explanation is given by $\mathrm{M} 2$.

...because of the lack of time, because the lack of resources, obviously, the faster you delegate and build a team, better organize, you can see other phases in the decision-making. [...] sometimes, time is the main resources that is needed and let other things go... - M2.

Mexican entrepreneurs have learned that when capital investments are beyond their financial capabilities, they need to find other alternatives. For instance, when entrepreneurs are not able to afford local, national or international brand equipment, they often decide to hire a local engineer to make a "similar" machine and work on home-made equipment. The main reason for this is that the entrepreneurs need to adapt to their aspiration level. Following are the statements from $\mathrm{M} 8$ and $\mathrm{M} 2$.

...sometimes, I have ideas, but it is hard for me to execute them, because of money, but bit by bit we are making progress. This is a packaging machine that actually cost one hundred and fifty thousand pesos, used. So, what I have done is purchased the parts and I am trying to put it together, [...] I am going to spend forty thousand pesos to make it - M8.

...yes, there is machinery, but really, like many things, costs are out of reality, no? [...] Then, you have to be creative and try to adapt them. You will not make a car, 
but you can invent a half-bicycle. We will not make an automatic Industrial fryer, but you can make the pan for frying, for example -M2.

When able to purchase equipment, Mexican entrepreneurs seem to prefer Mexican-made equipment or locally-made equipment as suggested by M1

... as an entrepreneur and owner of any machinery I will say, it is better to look for someone from here that can repair it, because for me, it represents a waste of time and money when that machine is not working - M1.

The insights from the Mexican sample raise additional questions for discussion: What are the possible explanations in relation to the Mexican entrepreneur's approach to capital budgeting decisions? Why do Mexican entrepreneurs prefer to make their own equipment, purchase locally-made or Mexican-made equipment, if in many cases international brands or well-known brands have more durability, are faster and produce better quality products? Ahead of a comparative discussion of our insights found for both Mexican and Canadian interviewees, potential explanations drawn from our interviews are shared below.

\begin{abstract}
Mexican entrepreneurs seem to be trying to avoid dependency on foreign technologies that could translate into expensive repairs and a long waiting repair period, instead, they prefer local suppliers that could quickly respond when they are needed. Mexican entrepreneurs seek to build a strong connection with local suppliers (engineers or local small firms) that could manufacture a "similar" type of machine that may not provide the same results but satisfies their needs. Deciding for locally-made or home-made equipment to a certain point, is seen to be a fast and frugal decision because the entrepreneur remembers that a past similar decision gave a good result, therefore entrepreneurs continue to rely on this type of decision-making. Trust might additionally explain a preference for such locally focussed decisions being made. Mexican entrepreneurs reported having trust relationships that have grown and can last over long time periods. In many cases, entrepreneurs referred to suppliers as friends.
\end{abstract}

\footnotetext{
While trust and long-term relations with suppliers seem to affect procurement decisions, it does not seem to transfer further, particularly if finances are involved. Mexican interviewees often gave the impression to have little trust towards non-family members, which restricts their possibilities to secure external funding. Mexican entrepreneurs seem to reject the idea to obtain external financing via new shareholders or partners. Instead, they tend to delay the capital investment decision by relying on various forms of bootstrap and family financing. Mexican entrepreneurs reported to heavily rely on internally generated resources together with personal and family financial resources. They have limited access to external financing via debt, and when they access these resources, the interest costs are high and usually require real estate collateral. With an unstable economy, decreasing purchase power of the Mexican peso and high exchange rate risk, Mexican entrepreneurs hence seem very cautious when engaging in capital investments that require a substantial amount of financial resources. Risk associated with the regional context seems to be an important element here. Based on our interviews, the financial limitations and the high level of uncertainty in the economy, might help explain why Mexican entrepreneurs appear less open to take higher levels of risk.
} 


\section{Capital budgeting in Canada}

Looking at how Canadian entrepreneurs search for capital budgeting alternatives, our insights from the interviews reveal that a variety of methods are used with the most common being searches on the internet, attendance at tradeshows, exchanges with their suppliers (yet, attributing them the role of sales people rather than objective informants) and assistance from competitors.

Similar to Mexican entrepreneurs, Canadian entrepreneurs use the internet and their contacts with suppliers to gather information. In addition, the entrepreneurs attend tradeshows to explore what capital investment alternatives are out there: types, origin, price, conditions, and capabilities. Canadian entrepreneurs canvas themselves rather knowledgeable about available options for potential capital investments:

Yeah, we participate in trade shows to present our products, but we also go to trade shows and expos that provide information about either packaging equipment, or tanks, or bulk powder handling equipment - that kind of thing - C11.

...for equipment trade shows... I do go every time just to get knowledge of what is new. I think you have to stay up on top to understand - C12

One of the most common methods practiced by Canadian entrepreneurs in our sample is searching for capital investment alternatives by approaching competitors. According to the Canadian interviewees, this is the most effective way to identify investments that might achieve the entrepreneurs' objectives. Canadian entrepreneurs in this particular sector, region, and company size are willing to share their capital investment experience with competitors, in many cases they go further by mentoring new competitors and generally seem to be rather supportive and trustworthy towards each other. As an entrepreneur put it, "we do not share our secret formula. We share our experience of capital investments; what works and what does not work" (C12). Other interviewees also provided past examples when such a technique was applied with success:

...we started doing the research about chocolatiers. Then, we said, okay, we need to talk to the chocolatiers. What are they doing? What are the machines they are favouring? Why are they favouring them? And then, that's when we came out with the perfect machine - C1.

Similar to Mexican entrepreneurs, Canadian entrepreneurs also pay attention to their financial resources to see what is affordable for their small business and aspiration level. However, different to the Mexican context, stringent Canadian food regulations force Canadian entrepreneur to purchase specific types of equipment that comply with food regulations. Canadian entrepreneurs tend to stop looking for alternatives when they have found an option that is acceptable to the entrepreneurs' aspiration levels and usually also is common among their competitors. As a simple explanation the interviewees justified their benchmark arguing that "what works for them [competitors] might work for me" (C12). 
Another difference between Mexican and Canadian entrepreneurs is that Canadian entrepreneurs are not looking for an affordable option per se, but the best equipment that they can afford. They tend to emphasize the importance of product or process characteristics that are expected to increase or maintain the quality of the production, quality is first. This stronger orientation towards quality found for Canadian entrepreneurs was explained through better access to financial resources. For instance, easier for Canadian entrepreneurs to get access to bank loans and government grants compared to Mexican entrepreneurs. Additionally, Canadians in our samples appeared more open to accept shareholders or partners (outside the family) in the business and also tend to formalise their ideas more clearly as they usually require business plans justifying and detailing required funds.

...I'm accustomed to developing three-to five-year capital plans... You know, oneto-three or three-to-five years, depending on if the three-to-five year plan gets a little fuzzy - you cannot always see that far - C6.

...because when you do your financials, you have to have a business plan. 'Where would you need that equipment?' You know, in order to get the money... No one sits there and says, 'there's the money'. You have to have a plan, because they want to make sure that you are paying. So, it takes planning- C12.

Canadians cannot be seen to more easily afford equipment per se. But they have different access to funds and hence can afford the equipment that the business plans allows them to obtain. Canadian entrepreneurs take decisions based on business plan (estimates), but also combine (or support) their "gut feeling" with quantitative analysis.

...absolutely, everything is justified with numbers. There's no using gut instinct only without the numbers - C4.

...You know, I'm a data guy; I like data, I look for data, but I don't make decisions solely on data - I put in my instincts- C6.

Canadian entrepreneurs do seem to rely less on family money and bootstrap financing. They reportedly have more access to financial resources, debt and/or equity than most Mexican entrepreneurs. The Canadian government and not-for-profit agencies help entrepreneurs via business grants to support the small business or via workshops to teach them business tools, e.g. business plan. In addition, Canada has a strong economic system, strong creditor's protection, lower exchange rate risk, and stronger purchase power, providing entrepreneurs a different set of opportunities for funding their investment.

When considering capital investment alternatives, Canadian entrepreneurs strongly consider product quality, and affordability (aspiration level). Canadian entrepreneurs rarely use home-made equipment. When the equipment is identified, Canadian entrepreneurs rather look for used equipment. While similar to our impression from the Mexican sample, finance and access to finance are key to the investment decision for Canadian entrepreneurs, too, however the latter seem to have more financial support and options available, to them but also face stronger food regulations that again limit their capital investment alternatives. 


\section{Discussion}

Using qualitative research, a constructivist perspective, and a bounded rationality lens, this study has explored capital budgeting decision-making of Canadian and Mexican entrepreneurs in two different regional contexts. This is an attempt to explore the capital budgeting decision-making in the small business and identify entrepreneurial practices in context (Outsios and Kittler, 2017), i.e. their specific patters with regard to decision-making and their consistency across (regional) contexts. This papers explores the capital budgeting decision-making experienced by the entrepreneur by considering the complexity of real-life situations (Emmanuel et al., 2010), and try to shed additional light on the role of context in the decision-making process (Chen, 2008; Carr and Tomkins, 1998; Carr et al., 2010).

While within accounting it initially appears to be merely a technical domain in which decisions seem to be guided by concise rules, practice suggests that it is not easy to isolate accounting problems from their social or national context (Choudhury, 1986; Carr and Harris, 2004) and there is increasing support for views to also consider personal understanding and practices (Northcott, 1991). By contextualizing entrepreneurs' capital budgeting decisionmaking, this research provides better understanding on how entrepreneurs from two different regional contexts search for capital budgeting alternatives and make decisions. Our research is in line with other recent studies that consider the role of context for strategic investments (Graham and Sathye, 2017; Carr and Harris, 2004; Alkaraan, 2016; Carneiro Lima et al., 2017; Elbanna and Fadol, 2016).

While our insights should not be misread as general statements about entrepreneurs and decision-making in Canada and Mexico, applicable to all sectors, regions or all types of capital investment decisions (Block, 2005; Chittenden and Derregia, 2015) this study provides insights at the nexus of managerial accounting and entrepreneurship with our insights stemming from two geographic contexts, contrasting the practices found at these locations. Adding to extant research this study illustrates variations in capital budgeting decisions resulting from their contextual setting (Alkaraan, 2016; Graham and Sathye, 2017; Huikku et al., 2018; Carneiro Lima et al., 2017; Elbanna and Fadol, 2016; Carr and Harris, 2004) and responds to the need to contextualize managerial accounting research (Parnell and Hatem, 1999; Harris, 2014; Efferin and Hopper, 2007).

Based on the insights from this study, both Mexican and Canadian entrepreneurs use a variety of ways to search for capital investment alternatives - but also differ in preferences and their approaches to make decisions. As discussed above, Mexican entrepreneurs rely more strongly on information from suppliers and Canadian entrepreneurs rely more on the experience of their competitors with similar investment decisions. In an attempt to explain the contextualised capital budgeting decision-making, this paper draws from the interviews and prior research considering contextual aspects (Harris and El-Massri, 2011), national culture (Holt, 1997; Graham and Sathye, 2017) and other possible determinant such as labour and financial markets, government support and the regulatory context in which decisions are made. 
With a look at external actors, one observation is that Canadian entrepreneurs seem to lend trust to (like-minded) externals, even competitors and share their capital investment experiences with them, while Mexican entrepreneurs do not easily trust non-family members and externals. Trust with their suppliers seems an exception observed in our interviews, but this was reported to take substantial time to develop. It could be that Canadian national culture showing higher individualism compared to the more collectivist Mexican national culture context (Hofstede, 2001) might explain a stronger fixation of trust on in group members and family. Yet, depending on the "in group" definition, our insights for Canada could also be seen to contradict Hofstede's data, as Canadian entrepreneurs seem to trust and feel responsible for their in-group of (competing) entrepreneurs more strongly than the Mexican entrepreneurs in our sample. Therefore, while this study agrees with other scholars in supporting the idea that national culture affects capital budgeting decision- making (Shields et al., 1991; Carr and Tomkins, 1998; Hermes et al., 2007; Carr et al., 2010; Graham and Sathye, 2017) this study cannot confirm that traditional etic studies, as represented in Hofstede's data, serve as an adequate basis for explanation.

This study also acknowledge that - even with adequate insights on cultural differences, possibly rooted in emic studies - differences between Canadian and Mexican entrepreneurs cannot be comprehensively explained by focussing on national culture (Tayeb, 2001). An example for the role of other contextual determinants is the consideration of the impact a capital budgeting decision was to make on non-family staff numbers. It was common to hear complaints from our Mexican interviewees over the behaviour of non-family member workers and criticism towards unfair protections that government agencies give to workers. According to Mexican entrepreneurs, they have little possibilities to lay off bad workers who benefit from protection given by the government. This might not only explain Mexican entrepreneurs' preference for capital investment decisions which do not lead to hiring requirements or even allows for redundancies. Additionally to the role of culture and demographics, this example highlights the role of labour legislation in understanding the important role of family in Mexican smaller firms. This could also be seen to illustrate a predecision control mechanism (Alkaraan and Northcott, 2007; Huikku et al., 2018)

Focusing on the economic context, Canada is seen to provide stronger financial support to small business compared to support received by our interviewees in Mexico. This might explain why Canadian entrepreneurs report to be more open to external funding than the Mexican informants in our study. Mexican entrepreneurs did report far less interest to involve new shareholders in order to raise funding in support to their strategic investments. Mexican entrepreneurs also reported concerns in taking bank loans, often requiring unfeasibly high collaterals to cover the lenders' risks while Canadian entrepreneurs seem to reduce default risk (or at least lower the lenders' perception of risk) by preparing business plans in support of their capital investment decisions. The latter could also seen as a means to better inform the decision-making as they are required to make implicit assumptions explicit and disclose the results of their research as part of the communication required with other practitioners (Kittler, 2018). A concise presentation of financial estimates, in the form of financial plan, it is a common pre-decision control used in capital investment decisions (Huikku et al., 2018). 
The political encouragement for small business and entrepreneurial activity also seems to affect differences in approaching capital budgeting decisions. Some Canadian entrepreneurs reported that they received assistance from government or from not-for profit organizations, for instance in developing their business plans. This was not reported by our Mexican sample, where some interviewees rather complained that they are a target of government agencies for paying high business taxes and unnecessary registration fees, supporting the idea that capital budgeting decisions vary between developed and developing countries (Kengatharan, 2016). Compared to Canada, Mexican entrepreneurs in our sample rely more on internally generated and family funds, which in most of the cases created capital investment delays (Chittenden and Derregia, 2015). The latter approach also reduces the need to follow a structured and formal strategic planning process (Carneiro Lima et al., 2017), to prepare business plans and financial statements, because there is no need to report to external funders. This is consistent with past research that planning helps to evaluate alternatives (Chwolka and Raith, 2012) and business plans help to increases the possibility of product development (Delmar and Shane, 2003).

\begin{abstract}
A possible explanation for the different levels of formalization towards capital budgeting decisions could also be found in the different regulatory contexts of both countries with more stringent food regulations found in Canada (Warren and Jack, 2018; Ball and Kittler, 2017). While previous research has also suggested how strategic investment decisions have played a role in even changing regulatory environments (and prior government policies), mainly observing larger incumbent firms (Warren and Jack, 2018), for the case of smaller actors (unless aggregated towards a uniform lobby) the causality seems reversed (which Ball and Kittler, 2019, recently discussed for green entrepreneurs in a similar industry context as Warren and Jack). In the context of smaller firms in the food processing industry, this study hence could argue that the regulatory environment, documented here in more stringent food standards in Canada affects capital budgeting decisions. For instance, Canadian entrepreneurs have less possibility to build their own equipment, while Mexican entrepreneurs with weaker food standard regulations did report of decisions to make rather than buy machinery or to rely on locally made, customized or used equipment, suggesting a wider set of alternatives.
\end{abstract}

\begin{abstract}
The discussion above has looked at different dimensions of the business environment to discuss how Mexican and Canadian entrepreneurs in our sample differ in their searches informing capital budgeting decisions and also addressed why they might stop searching and make decisions that meet their aspiration level. On both sides, the use of "gut feeling" was reported, yet complemented with very-little quantitative analysis for the Mexican entrepreneurs and (due to higher formal regulations) supported more strongly with analytical components for Canadian entrepreneurs. Yet, in both cases, affordability is a key factor in satisficing. In addition, it seems that Canadian and Mexican entrepreneurs are influenced by prior experiences and "rules of thumbs". For instance, Mexican entrepreneurs seem to be influenced particularly by local suppliers and less involve (or trust) competitors, while Canadian entrepreneurs seem to value their competitors' experiences with similar investments as a key source in their search for information. These insights suggest that not only the wider environment but also the competitive environment does influence search and satisficing but also renders the observations made subject to specific contexts (Gigerenzer
\end{abstract}


and Selten, 2001). Accepting a role of context and the specificity of environment, culture and time would call for further qualitative researches on strategic investment decisions.

\section{Conclusions, Limitations and Contributions}

This article explores how capital budgeting decision-making differs across two regional contexts and how elements of bounded rationality are found in the decision-making processes for Canadian and Mexican entrepreneurs. This study contributes context specific insights to extant research in the field of managerial accounting and entrepreneurship by focusing on how and why capital budgeting decisions were made (differently). Following this overall aim, the study departs from the focus on financial or survey data usually found in studies subject to a positivist lens. Instead, this study uses a qualitative research approach with foundations in constructivist grounded theory (Charmaz, 2014) to explore the capital budgeting decision-making practices experienced by the entrepreneur. This naturalistic research approach to capital budgeting decision-making in our view is a welcome addition to methodological pluralism benefitting accounting research (Hoque, 2006). Its flexibility and inductive strategy allowed us capturing the complexity of the entrepreneurs' decisions and practice in context. In addition, it helped to aid our understand of capital investment decisions lived by the entrepreneur in a real organization (Harris et al., 2016).

\footnotetext{
Our empirical insights suggest that bounded rationality is present in capital investment decision-making at the individual decision-making level. Canadian and Mexican entrepreneurs take decisions under conditions of bounded rationality but also that decisions and the role of bounded rationality towards decisions are affected by the regional context contributing to our knowledge base by contextualizing accounting research (Layder, 1993), particularly by contextualizing the capital budgeting decision-making (Elmassri et al., 2016). This study departs from instrumental approaches stemming from mainstream managerial accounting research and practice, which often de-contextualize and simplify findings from positivist approaches (Van der Meer-Kooistra and Vosselma, 2012). Our one-on-one, face-toface, open-ended interviews relating to the entrepreneurs' capital budgeting experiences seemed to be the less conventional, yet more insightful method to elicit information.
}

Despite careful consideration of the focus of the study and the method related decisions above, a few potential limitations should not be omitted. For some, this might even start with the focus on entrepreneurs/individual taken within this research. Low and Macmillan (1988) suggested early on to explore entrepreneurship from different levels of analysis, but there is little guidance and scholars do not agree on what level(s) of analysis should be decided for (Davidsson and Wiklund, 2001). By selecting the individual as a unit of analysis for this study, it should not be seen as contradicting Low and Macmillan's (1988) suggestion, but rather a decision for the unit of analysis that best responds to naturalistic inquiry (Lincoln and Guba, 1985) and also matches the objective of the study. Selecting the individual decision maker also responds to calls for a better understanding of capital investment decisions (Emmanuel et al., 2010; Harris et al., 2016) This study recognizes that additional levels of analysis or their combinations could yield further insights and contributions to the aim of this study (Welter, 2011). However, the latter is more to be seen as an invitation for further research rather than a limitation. 
Looking at the body of research on capital budgeting at the small business level, existing research appears limited in scale and scope and lends itself to in-depth insights. With much of the research in capital investment being associated with quantitative methods (Alkaraan and Northcott, 2006), the qualitative route taken in this paper might face additional criticism, particularly from proponents of a more positivist lens. However, this should not be seen as a limitation but rather for the benefits this less travelled path entails. This also aligns with Welter (2011), who argues that the gap in multi-context analysis partly results from the neglect of qualitative methods, which would better allow capturing the richness and diversity of the context.

Despite some justifiable limitations, our study advances the knowledge of managerial accounting in several ways by taking a more holistic approach of the capital budgeting decision-making, as suggested by Harris et al. (2016). The insights from this study do not intend to provide a recipe to entrepreneurs in how to take decisions, but they provide a better understanding of the decision-making process in the entrepreneur's context, this is the study's conceptual relevance (Alexander and Seidi, 2010). Our insights suggest that the basic ideas of bounded rationality, particularly the sequence of search and satisficing applies to both the Mexican and the Canadian contexts, yet in different ways. The differences relate among others on how information is searched and from whom it is retrieved. For instance, Canadian entrepreneurs in the food-processing sector reported that competitors seem a trustworthy source of information, while Mexicans rather look at the information they retrieve from sales people once a trustful relationship has been built over time. Satisficing also shows differences in how affordability is assessed. Our data reveals empirical insight into the decision-making processes of entrepreneurs and show that context matters in how bounded rationality is reflected in these decisions. Future research could explore if bounded rationality is nation-specific, as Elbanna and Fadol (2016) found in the case of intuition in strategic decision-making process.

Insights from this study further suggest that education has a connection with the use of "gut feeling" as inversely related to the use of planning tools, e.g. Danielson and Scott (2006), but connections can be made to a wider set of contextual elements in the business environment. The researcher found cases where the entrepreneurs relied on "gut feeling" due to time constraints, lack of information or no previous experience on that particular type of decision despite having a solid business background. This study also gives evidence of cases where entrepreneurs without formal education background and experience were able to approach decisions in a more "prepared" manner and sought help from government and community organizations to prepare business plans. The insights from this research encourage bringing to the classroom a more holistic approach of capital budgeting decision-making. It was shown that Western practices are not necessarily applicable in other regional context. Both, Mexican and Canadian entrepreneurs may use the insights from this study to learn about new approaches to capital budgeting decisions, however, contextual factors (Alkaraan and Northcott, 2013) may prevent (or also facilitate) the implementation of these approaches. 


\section{References}

Acs ZJ, Audretsch DB and Strom RJ. (2009) Entrepreneurship, growth, and public policy. Cambridge: University Press.

Alexander N and Seidi D. (2010) That's relevance! Different forms of practical relevance in management science. Organization Studies 31(9\&10): 1257-1285.

Alkaraan F. (2016) Strategic investment decision-making - scanning and screening investment opportunities: The expansion of Guinness in West Africa. Meditari Accountancy Research 24(4).

Alkaraan F and Northcott D. (2006) Strategic capital investment decision-making: A role for emergent analysis tools?: A study of practice in large UK manufacturing companies. The British Accounting Review 38(2): 149-173.

Alkaraan F and Northcott D. (2007) Strategic investments decision making: the infleunce of predecision control mechanism. Quarterly Research in Accounting and Management 4(2): 133.

Alkaraan F and Northcott D. (2013) Strategic investment decision-making processes: the influence of contextual factors. Meditari Accountancy Research 21(2): 117-143.

Andor G, Mohanty SK and Toth T. (2015) Capital budgeting practices: A survey of Central and Eastern European firms. Emerging Markets Review 23: 148-172.

Arnold GC and Hatzopoulos PD. (2000) The theory-practice gap in capital budgeting: Evidence from the United Kingdom. Journal of Business Finance \& Accounting 27(5/6): 603-626.

Baker R. (2014) Qualitative reearch in accounting: the North American perspective. Qualitative Research in Accounting \& Management 11(4): 278-285.

Ball C and Kittler MG. (2017) Removing environmental market failure through support mechanisms: Insights from green start-ups in the British, French and German energy sectors. Small Business Economics, forcoming.

Bamford CE, Dean TJ and McDougall PP. (2000) An examination of the impact of initial founding conditions and decisions upon the performance of new bank start-ups. Journal of Business Venturing 15(3): 253-277.

Beck T and Demirguc-Kunt A. (2006) Small and medium-size enterprises: Access to finance as a growth constraint. Journal of Banking \& Finance 30(11): 2931-2943.

Bellouma M. (2010) Effect of capital investment on working capital management: Evidence on tunisian export SMEs. International Journal of Finance 22(3): 6497-6509.

Ben-Caleb E, Uwuigbe U and Agbude GA. (2013) Capital budgeting, government policies and the performance of SMEs in Nigeria: A hypothetical case analysis. IFE Psychologia: An International Journal 21(1): 55-73.

Bierman Jr H and Smidt S. (2012) The capital budgeting decision: economic analysis of investment projects.: Routledge.

Block S. (1997) Capital budgeting techniques used by small business firms. Engineering Economist 42(4): 289-302.

Block S. (2005) Are there differences in capital budgeting procedures between industries? an empiricla study. Engineering Economist 50(1): 55-67.

Block S. (2007) Are "real options" actually used in the real world? The Engineering Economist 52(3): 255-267.

Braggion F, Dwarkasing M and Ongena S. (2018) Household wealth inequality, entrepreneurs' financial constraints, and the great recession: evidence from the Kauffman Firm Survey. Small Business Economics 50(3): 533-543.

Bruyat C and Julien P-A. (2001) Defining the field of research in entrepreneurship. Journal of Business Venturing 16(2): 165-180.

Burmeister K and Schade C. (2007) Are entrepreneurs' decisions more biased? An experimental investigation of the susceptibility to status quo bias. Journal of Business Venturing 22(3): 340362. 
Burns RM and Walker J. (2009) Capital budgeting surveys: The future is now. Journal of Applied Finance 19(1/2): 78-90.

Busenitz L and Barney J. (1997) Differences between entrepreneurs and managers in large organizations: Biases and heuristics in strategic decision-making. Journal of Business Venturing 12(1): 9-30.

Butler R, Davies L, Pike R, et al. (1991) Strategic investment decision-making: complexities, politics and processes. Journal of Management Studies 28(4): 395-415.

Canada AaA-F. (2019) Overview of the food and beverage processing industry. Available at: www.agr.gc.ca.

Carneiro Lima A, Giesbrecht da Silveira J, Ney Matos F, et al. (2017) A qualitative analysis of capital budgeting in cotton ginning plants. Qualitative Research in Accounting \& Management 14(3): 210-229.

Carr C and Harris S. (2004) The impact of diverse national values on strategic investment decisions in the context of globalization. International Journal of Cross Cultural Management 4(1): 77-99.

Carr C, Kolehmainen K and Mitchell F. (2010) Strategic investment decision making practices: A contextual approach. Management Accounting Research 21(3): 167-184.

Carr C and Tomkins C. (1998) Context, culture and the role of the finance function in strategic decisions. A comparative analysis of Britain, Germany, the USA and Japan. Management Accounting Research 9(2): 213-239.

Carter RB and Van Auken H. (2005) Bootstrap financing and owners' perceptions of their business constraints and opportunities. Entrepreneurship \& Regional Development 17(2): 129-144.

Cassar G. (2010) Are individuals entering self-employment overly optimistic? An empirical test of plans and projections on nascent entrepreneur expectations. Strategic Management Journal 31(8): 822-840.

Charmaz K. (2014) Constructing Grounded Theory, London: Sage.

Chen S. (2008) DCF techniques and nonfinancial measures in capital budgeting: A contingency approach analysis. Behavioral Research in Accounting 20(1): 13-29.

Chittenden F and Derregia M. (2015) Uncertainty, irreversibility and the use of "rule of thumb" in capital budgeting. The British Accounting Review 47(3): 225-236.

Choudhury N. (1986) In search for relevance in management accounting reseach. Accounting and Business Research 17(65): 21-32.

Chwolka A and Raith MG. (2012) The value of business planning before start-up - A decisiontheoretical perspective. Journal of Business Venturing 27(3): 385-399.

Corley K. (2011) The coming of age for qualitative research: Embracing the diversity of qualitative methods. Academy of Management Journal 54(2): 233-237.

Davidsson P and Honig B. (2003) The role of social and human capital among nascent entrepreneurs. Journal of Business Venturing 18(3): 301-331.

Davidsson P and Wiklund J. (2001) Levels of analysis in entrepreneurship research: Current research practice and suggestions for the future. Entrepreneurship: Theory \& Practice 25(4): 81-99.

Delmar F and Shane S. (2003) Does business planning facilitate the development of new ventures? Strategic Management Journal 24(12): 1165-1185.

Drury C and Tayles M. (1996) UK capital budgeting practices: Some additional survey evidence. The European Journal of Finance 2(4): 371-388.

Dushnitsky G. (2010) Entrepreneurial optimism in the market for technological inventions. Organization Science 21(1): 150-167.

Efferin S and Hopper T. (2007) Management control, culture and ethnicity in a Chinese Indonesia company. Accounting, Organizations and Society 32(3): 223-262.

Elbanna S and Fadol Y. (2016) The rol of context in intuitive decision-making. Journal of Management \& Organization 22(5): 642-661.

Elmassri M, Harris E and Carter D. (2016) Accounting for strategic investment decision-making under extreme uncertainty. The British Accounting Review 48(2): 151-168. 
Emmanuel C, Harris E and Komakech S. (2010) Towards a better understanding of capital investment decisions. Journal of Accounting \& Organizational Change 6(4): 477-504.

Emmanuel C, Harris E and Komakech S. (2011) Towards a better understandingof capital investment decisions. Journal of accounting and Organizational Changes 6(4): 477-504.

Forbes DP. (2005) Are some entrepreneurs more overconfident than others? Journal of Business Venturing 20(5): 623-640.

Galvin P. (2014) A new vision for the Journal of Management \& Organization: The role of context. Journal of management and Organization 18(7): 583-591.

Garrison R, Webb A and Libby T. (2018) Managerial Accounting, Canada: McgrawHill Ryerson.

Gartner WB and Birley S. (2002) Introduction to the special issue on qualitative methods in entrepreneurship research. Journal of Business Venturing 17(5): 387-395.

Geertz C. (1973) The interpretation of cultures: Selected essays, New York: Basic books.

Gigerenzer G. (2008) Why heuristics work. Perspectives on psychological science 3(1): 20-29.

Gigerenzer $\mathrm{G}$ and Selten R. (2001) Rethinking rationality. In: Gigerenzer G and Selten R (eds) Bounded Rationality The Adaptive Tool Box. Cambridge, Massachusetts, US: The MIT Press, 1-12.

Gilhooly KJ. (1988) Thinking: Directed, undirected and creative, San Diego, CA: Academic Press.

Glaser B and Strauss A. (1967) The discovery of grounded theory, Chicago: Aldine.

Graham PJ and Sathye M. (2017) Does national culture impact capital budgeting systems? Australasian Accounting, Business \& Finance Journal 11(2): 43-60.

Grbich C. (2012) Qualitative data analysis: An introduction, London: Sage.

Hamid NA, Noor RM and Zain MM. (2011) Factors affecting SMEs successful utilization of tax incentives in manufacturing sectors. Malaysian Accounting Review 10(1): 1-16.

Harada N and Honjo Y. (2005) Does the creative business promotion law enhance SMEs capital investments? Evidence from a panel dataset of unlisted SMEs in Japan. Japan and the World Economy 17(4): 395-406.

Harris E. (2014) Feel the risk: strategic investment decisions in an uncertain world. In: Otley D and Soin K (eds) Management Control and Uncertainty. London: Palgrave Macmillan.

Harris E and El-Massri M. (2011) Capital investment appraisal. Review of Management Accounting Research. London: Palgrave Macmillan, 343-377.

Harris E, Emmanuel C and Komakech S. (2009) Managerial judgement and strategic investment decisions - a cross-sectional survey, Oxford: Elsevier, CIMA Publishing.

Harris E, Northcott D, Elmassri MM, et al. (2016) Theorising strategic investment decision-making using strong structuration theory. Accounting, auditing \& accountability journal 29(7): 1771203.

Hermes N, Smid P and Yao L. (2007) Capital budgeting practices: A comparative study of the Netherlands and China. Internnational Business Review 16(5): 630-654.

Ho SS and Pike RH. (1991) Risk analysis in capital budgeting contexts simple or sophisticated? Accounting and Business Research 21(83): 227-238.

Hofstede G. (2001) Culture's consequences, London: Sage Publications, Inc.

Holt DH. (1997) A comparative study of values among Chinese and U.S. entrepreneurs: Pragmatic convergence between contrasting cultures. Journal of Business Venturing 12(6): 483-505.

Holtz-Eakin D, Joulfaian D and Rosen HS. (1994) Sticking it out: Entrepreneurial survival and liquidity constraints. Journal of Political Economy 102(1): 53.

Hoque Z. (2006) Introduction. In: Hoque Z (ed) Methodological Issues in Accounting Research. Geelong, Australia: Spiramus.

House R, Hanges P, Javidan M, et al. (2004) Culture, Leadership, and Organizations: The GLOBE study of 62 societies London: SAGE Publications.

Huikku J. (2008) Managerial uses of post-completion auditing of capital investments. The Finnish Journal of Business Economics 57(2): 139-164.

Huikku J, Karjalainen J and Sepala T. (2018) The dynamis of pre-decision controls in appraisal of strategic investments. The British Accounting Review 50(5): 516-538. 
Jackson S. (2010) Mulling over Massachusetts: Health insurance mandates and entrepreneurs. Entrepreneurship Theory and Practice 34(5): 909-931.

Jones BD. (1999) Bounded Rationality. Annual Review of Political Science 2(1): 297-321.

Kahneman D, Slovic $P$ and Tversky A. (1982) Judgment under uncertainty: Heuristics and biases. Cambridge: Cambridge University Press.

Kemper EA, Stringfield S and Teddlie C. (2003) Mixed methods sampling strategies in social science research. In: Tashakkori A and Teddlie C (eds) Handbook of mixed methods in social \& behavioural research. Thounand, Oaks CA.: Sage, 273-296.

Kengatharan L. (2016) Capital budgeting theory and practice: A review and agenda for future research. Applied Economics and Finance 3(2): 15-38.

Kim SH. (1981) Current capital budgeting practices. Management Accounting 62(12): 26-30.

Kingsley GA and Reed PN. (1991) Decision process models and organizational context: Level and sector make a difference. Public Productivity and Management Review 14(4): 397-413.

Kittler MG. (2018) Do we understand each other? Discussing academic exchange from a crosscultural communication perspective. . International Studies of Management \& Organisation 48(3): 333-351.

Langley A, Mintzberg H, Pitcher P, et al. (1995) Opening up decision making: The view from the black stool. Organization Science 6(3): 260-279.

Langowitz N and Minniti M. (2007) The entrepreneurial propensity of women. Entrepreneurship Theory and Practice 31(3): 341-364.

Layder D. (1993) New Strategies in Social Research, Oxford: Polity Press.

Lazaridis IT. (2004) Capital budgeting practices: A survey in the firms in cyprus. Journal of Small Business Management 42(4): 427-433.

Lefley F. (1994) Capital investment appraisal of advanced manufacturing technology. The International Journal of Production Research 32(12): 2751-2776.

Leigh NG and Blakely EJ. (2013) Planning Local Economic Development: Theory and Practice, Thousand Oaks, CA: Sage.

Levesque M, Minniti M and Shepherd D. (2009) Entrepreneurs' decisions on timing of entry: Learning from participation and from the experiences of others. Entrepreneurship Theory and Practice 33(2): 547-570.

Liljeblom E and Vaihekoski M. (2004) Investment evaluation methods and required rate of return in Finnish publicly listed companies. 9-24.

Lincoln Y and Guba E. (1985) Naturalistic Inquity, London: Sage Plublications.

Low MB and MacMillan IC. (1988) Entrepreneurship: Past research and future challenges. Journal of Management 14(2): 139-161.

Lowe RA and Ziedonis AA. (2006) Overoptimism and the performance of entrepreneurial firms. Management Science 52(2): 173-186.

Ma Y and Tayles M. (2011) On the emergence of strategic management accounting: An institutional perspective. Accounting and Business Research 39(5): 473-495.

McKelvie A, Haynie JM and Gustavsson V. (2011) Unpacking the uncertainty construct: Implications for entrepreneurial action. Journal of Business Venturing 26(3): 273-292.

Mexico-Now. (2016) Inside Mexico's processed food industry. Available at: www.mexico-now.com.

Moore DA, Oesch JM and Zietsma C. (2007) What competition? Myopic self-focus in market-entry decisions. Organization Science 18(3): 440-454.

Muller E and Zimmermann V. (2009) The importance of equity finance for R\&D activity. Small Business Economics 33(3): 303-318.

Northcott D. (1991) Rationality and decision making in capital budgeting. The British Accounting Review 23(3): 219-233.

Outsios G and Kittler MG. (2017) The minset of UK environmental entrepreneurs: A habitus perspective. International Small Business Journal 36(3): 285-306.

Palich LE and Bagby DR. (1995) Using cognitive theory to explain entrepreneurial risk-taking: Challenging conventional wisdom. Journal of Business Venturing 10(6): 425-438. 
Papadakis VM, Lioukas S and Chambers D. (1998) Strategic decision-making processes: The role of management and context. Strategic Management Journal 19(2): 115-147.

Parker SC. (2009) Can cognitive biases explain venture team homophily? Strategic Entrepreneurship Journal 3(1): 67-83.

Parnell J and Hatem T. (1999) Cultural antecedents of behavioral differences between Egyptians and Americans managers. Journal of Management Studies 36(3): 399-418.

Patton M. (2002) Qualitative research and evaluation methods Thousand Oaks, CA: Sage.

Petracca E. (2017) A cognition paradigm clash: Simon, situated cognition and the interpretation of bounded rationality. Journal of Economic Methodology 24(1): 20-40.

Phelan SE. (1997) Exposing the illusion of confidence in financial analysis. Management Decision 35(2): 163-168.

Pike R. (1996) A longitudinal survey on capital budgeting practices. Journal of Business Finance \& Accounting 23(1): 79-92.

Pike RH and Wolfe MB. (1988) Capital budgeting for the 1990's: A review of capital investment trends in larger companies, London: Chartered Institute of Management Accountants.

Porter ME. (1991) Towards a dynamic theory of strategy. Strategic Management Journal 12(S2): 95117.

Powell GN and Greenhaus JH. (2010) Sex, gender, and decisions at the family, work interface. Journal of Management 36(4): 1011-1039.

Qu S and Dumay J. (2011) The qualitative research interview. Qualitative Research in Accounting \& Management 8(3): 238-264.

Roberts $\mathrm{H}$ and Gnan L. (2017) Welcoming family business into the accounting family: An introduction to the special issue. Qualitative Research in Accounting \& Management 14(2): 106-110.

Robinson Jr RB and Pearce JA. (1983) The impact of formalized strategic planning on financial performance in small organizations. Strategic Management Journal 4(3): 197-207.

Ross SA, Westerfield RW, Jaffe J, et al. (2008) Corporate Finance, Canada: McGraw-Hill Ryerson.

Ross SA, Westerfield RW, Jordan B, et al. (2016) Corporate Finance, Canada: McGraw-Hill Ryerson.

Ryan PA and Ryan GP. (2002) Capital budgeting practices of the Fortune 1000: How have things changed? Journal of Business \& Management 8(4): 355-364.

Saukkonen N, Laine T and Suomala P. (2018) Utilizing management accounting information for decision-making: Limitations stemming from the process structure and the actors involved. Qualitative Research in Accounting \& Management 15(2): 181-205.

Schendel D. (1994) Strategy: Search for new paradigms. Strategic Management Journal 15(S2): 1-4.

Schumpeter JA. (1961) The Theory of Economic Development An Inquiry into Profit, Capital, Credit, Interest and the Business Cycle, New York: Oxford University Press.

Shepherd DA, Haynie JM and McMullen JS. (2012) Confirmatory search as a useful heuristic? testing the veracity of entrepreneurial conjectures. Journal of Business Venturing 27(6): 637-651.

Shepherd DA, Williams TA and Patzelt H. (2014) Thinking about entrepreneurial decision making review and research agenda. Journal of Management 41(1): 11-46.

Shields M, Chow C, Kato Y, et al. (1991) Management accounting practices in U.S. and Japan: Comparative survey findings and research implications. Journal of International Financial Management \& Accounting 3(1): 61-77.

Simon H. (1957) Administrative Behavior: A Study of Decision-Making process in Administrative Organizations., New York: The Free Press.

Simon HA. (1955) A behavioral model of rational choice. The Quarterly Journal of Economics 69(1): 99-118.

Simon HA. (1976) Administrative Behavior, New York: Cambridge Univ Press.

Simon HA. (1979) Rational decision making in business organization. American Economic Review 69(4): 493-513.

Simon HA. (1981) The Sciences of the Artificial. MIT Press. 
Simon M, Houghton SM and Aquino K. (2000) Cognitive biases, risk perception, and venture formation: How individuals decide to start companies. Journal of Business Venturing 15(2): 113-134.

Sinkovics RR, Penz E and Ghauri PN. (2008) Enhancing the trustworthiness of qualitative research in international business. Management International Review 48(6): 689-713.

Swain MR and Haka SF. (2000) Effects of information load on capital budgeting decisions. Behavioral Research in Accounting 12: 171-198.

Szirmai A, Naude W and Goedhuys M. (2011) Entrepreneurship, Innovation, and Economic Development: Oxford University Press.

Tayeb M. (2001) Conductive research across cultures: Overcoming drawbacks and obstacles. International Journal of Cross Cultural Management 1(1): 91-108.

Todd PM and Gigerenzer G. (2003) Bounding rationality to the world. Journal of Economic Psychology 24(2): 143-165.

Tversky A and Kahneman D. (1974) Judgment under uncertainty: Heuristics and biases. Science 185(4157): 1124-1131.

Van der Meer-Kooistra J and Vosselma E. (2012) Research paradigms, theoretical pluralism and practical relevance of managerial accounting knowledge. Qualitative Research in Accounting \& Management 9(3): 245-264.

Verbeeten FH. (2006) Do organizations adopt sophisticated capital budgeting practices to deal with uncertainty in the investment decision?: A research note. Management Accounting Research 17(1): 106-120.

Vincent VC. (1996) Decision-making policies among Mexican-American small business entrepreneurs. Journal of Small Business Management 34(4): 1-13.

Warren L and Jack L. (2018) The capital budgeting process and the energy trilemma- A strategic conduct analysis. The British Accounting Review 50(5): 481-496.

Welter F. (2011) Contextualizing entrepreneurship-conceptual challenges and ways forward. Entrepreneurship: Theory \& Practice 35(1): 165-184. 
Table 1: Overview of Mexican participants

\begin{tabular}{|c|c|c|c|c|c|c|}
\hline $\begin{array}{c}\text { Sample } \\
\text { ID }\end{array}$ & $\begin{array}{c}\text { Type of } \\
\text { Organization }\end{array}$ & Food Sector & $\begin{array}{c}\text { Business } \\
\text { Years }\end{array}$ & $\begin{array}{c}\text { Business } \\
\text { Size }\end{array}$ & Education & Age \\
\hline M1 & Corporation & Salsa & +20 & 10 & High School & 61 \\
\hline M2 & Corporation & Snack & +50 & 25 & Highschool & 72 \\
\hline M3 & Corporation & Snack & +100 & 130 & Business & 62 \\
\hline M4 & Corporation & Snack & 18 & 20 & College & 43 \\
\hline M5 & Proprietorship & Snack & +50 & 5 & Elementary & 75 \\
\hline M6 & Proprietorship & Snack & +48 & 12 & Elementary & +80 \\
\hline M7 & Proprietorship & Snack & 11 & 16 & High school & 52 \\
\hline M8 & Proprietorship & Snack & 11 & 10 & teacher & 57 \\
\hline M9 & Corporation & Olive oil bottler & +55 & 15 & High school & +70 \\
\hline M10 & Corporation & Beverage & +22 & 243 & Architect & 52 \\
\hline M11 & Corporation & Water bottler & 8 & 6 & lawyer & 44 \\
\hline M12 & Corporation & Snack & +30 & 240 & High school & 49 \\
\hline M13 & Corporation & Beverage & +59 & 12 & Business & 56 \\
\hline M14 & Corporation & Bread Manufactory. & 32 & 250 & Elementary school & 65 \\
\hline M15 & Corporation & Beverage & 1 & 8 & & 45 \\
\hline M16 & Corporation & Snack & +50 & 45 & High school & 33 \\
\hline M17 & Corporation & Salsa & 53 & 15 & High school & 72 \\
\hline M18 & Corporation & Salsa & 65 & 135 & High school & 60 \\
\hline M19 & Corporation & Beverage & 37 & 25 & Business & $60-65$ \\
\hline M20 & Proprietorship & Beverage & 5 & 7 & Economist & 47 \\
\hline
\end{tabular}


Table 2: Overview of Canadian participants

\begin{tabular}{|c|c|c|c|c|c|c|}
\hline $\begin{array}{l}\text { Sample } \\
\text { ID }\end{array}$ & $\begin{array}{c}\text { Type of } \\
\text { Organization }\end{array}$ & Food Sector & $\begin{array}{l}\text { Business } \\
\text { Years }\end{array}$ & $\begin{array}{c}\text { Business } \\
\text { Size }\end{array}$ & Education & Age \\
\hline $\mathrm{C} 1$ & Proprietorship & Confectionary & 5 & 3 & Business & 54 \\
\hline $\mathrm{C} 2$ & Proprietorship & Bread Manufacturer. & 25 & 6 & Elementary & 69 \\
\hline $\mathrm{C} 3$ & Proprietorship & Bread Manufactory & 18 & $5-10$ & Business & 45 \\
\hline $\mathrm{C} 4$ & Corporation & Snack & 20 & 22 & High school & $40-45$ \\
\hline $\mathrm{C} 5$ & Corporation & Bread Manufacturer. & +50 & 25 & High school & 75 \\
\hline C6 & Corporation & Cereal & +10 & 75 & Business & $35-40$ \\
\hline $\mathrm{C} 7$ & Corporation & Confectionary & +25 & 15 & High school & 60 \\
\hline $\mathrm{C} 8$ & Proprietorship & $\begin{array}{c}\text { Chocolate } \\
\text { Confectionary }\end{array}$ & 14 & 8 & $\begin{array}{l}\text { Chocolatier } \\
\text { certificate }\end{array}$ & $60-65$ \\
\hline C9 & Proprietorship & Water Bottler & - & 3 & Nurse & $50-55$ \\
\hline $\mathrm{C} 10$ & Proprietorship & Confectionary & 4 & 3 & $\begin{array}{l}\text { Chocolatier } \\
\text { certificate }\end{array}$ & 40 \\
\hline $\mathrm{C} 11$ & Corporation & Beverage & 30 & 14 & Business & $50-55$ \\
\hline $\mathrm{C} 12$ & Corporation & Bread Manufacturer. & 32 & 24 & High school & 42 \\
\hline $\mathrm{C} 13$ & Proprietorship & Beverage & 2 & 4 & High school & $40-45$ \\
\hline $\mathrm{C} 14$ & Corporation & $\begin{array}{l}\text { Ice Cream } \\
\text { Manufactory }\end{array}$ & 37 & 30 & Engineer & +60 \\
\hline $\mathrm{C} 15$ & Corporation & Beverage & 18 & $10-15$ & Business & +35 \\
\hline $\mathrm{C} 16$ & Corporation & Snack & 57 & - & Engineer & 42 \\
\hline $\mathrm{C} 17$ & Proprietorship & Beverage & 19 & 50 & High school & +50 \\
\hline $\mathrm{C} 18$ & Proprietorship & Snacks & 16 & $25-30$ & sociology & 40 \\
\hline C19 & Proprietorship & Beverage & 1 & 3 & High school & $35-40$ \\
\hline $\mathrm{C} 20$ & Proprietorship & Beverage & 15 & $4-5$ & High school & $45-50$ \\
\hline
\end{tabular}


Table 3. Similarities and differences in the use of bounded rationality, between Canadian and Mexican entrepreneurs.

\begin{tabular}{|l|l|l|}
\hline \multicolumn{1}{|c|}{ Satisficing } & \multicolumn{1}{|c|}{ Mexican Entrepreneurs } & \multicolumn{1}{c|}{ Canadian Entrepreneurs } \\
\hline $\begin{array}{l}\text { Searching } \\
\text { (how) }\end{array}$ & $\begin{array}{l}\text { Internet, industry magazines } \\
\text { and suppliers. }\end{array}$ & $\begin{array}{l}\text { Internet, industry Magazines, } \\
\text { trade shows and competitors. }\end{array}$ \\
\hline $\begin{array}{l}\text { Stopping } \\
\text { (why) }\end{array}$ & $\begin{array}{l}\text { Entrepreneurs stop searching } \\
\text { when they have found an } \\
\text { alternative that is affordable and } \\
\text { satisfies the entrepreneur's } \\
\text { needs and aspiration level. }\end{array}$ & $\begin{array}{l}\text { Entrepreneurs stop looking when } \\
\text { they have found an alternative } \\
\text { (shared by the competitor) that } \\
\text { satisfies the entrepreneur's needs } \\
\text { and aspiration level. }\end{array}$ \\
\hline $\begin{array}{l}\text { Decision } \\
\text { (What) }\end{array}$ & $\begin{array}{l}\text { Most common: Mexicans prefer } \\
\text { Mexican-made, locally-made or } \\
\text { home-made equipment. } \\
\text { Capital budgeting decisions are } \\
\text { taken to replace non-family } \\
\text { member workers. "gut feeling" } \\
\text { and/or experience. }\end{array}$ & $\begin{array}{l}\text { Most common: Canadians prefer } \\
\text { equipment that produces high } \\
\text { quality product. } \\
\text { Business plan with "gut feeling", } \\
\text { and/or experience. }\end{array}$ \\
\hline $\begin{array}{l}\text { Why is it in this } \\
\text { way? }\end{array}$ & $\begin{array}{l}\text { Financial limitations. } \\
\text { Rely on Internally generated } \\
\text { funds (or family financing). } \\
\text { High interest cost. } \\
\text { Reduce technical dependency } \\
\text { from imported equipment. }\end{array}$ & $\begin{array}{l}\text { Financial limitations. } \\
\text { Rely on external financing. } \\
\text { Easier access to creditors and } \\
\text { new shareholders. }\end{array}$ \\
\hline Context & $\begin{array}{l}\text { Weak Mexican food regulations } \\
\text { High labour cost. } \\
\text { High exchange interest risk } \\
\text { Lower level of trust to non- } \\
\text { family members. } \\
\text { Low government support. }\end{array}$ & $\begin{array}{l}\text { Strong Canadian food } \\
\text { regulations. } \\
\text { Strong creditor's protection. } \\
\text { Trust in the system. } \\
\text { Higher government support } \\
\text { (grants, business workshops). }\end{array}$ \\
\hline
\end{tabular}




\section{Appendix 1 - Interview guide (Adapted from Charmaz 2014)}

Section 1- Entrepreneur's demographic information.

a. What type of business organization is your company?

b. How many years of business does your company have?

c. How many people work in your company?

d. What product(s) does your company produce?

e. What level of education do you have?

f. What is your age?

g. How many years have you been entrepreneur?

h. Do you have previous work experience in the same field that your current business? Yes/No

i. Are you the founder/manager and responsible of the capital investment decisions in this company? Yes/ no.

j. During the lasts years, have you invest in fixed assets for your organization? What type?

Section 2- Entrepreneur's capital investment decision-making experience

a. Tell me about the events that lead up to identify the need of a capital investment.

b. Tell me about how did you look for the investment alternatives? What did you look for?

c. Tell me about your capital investment experience.

d. If you recall, what were the barriers during the searching for capital investment alternatives?

e. Who, if anyone, was involved? How were they involved? Who has been the most helpful during this process?

f. When did you decide to stop searching more capital investment alternatives? Why?

g. How did you select your "best" capital investment alternatives? Could you tell me that contributed to the selection of this capital investment?

h. Is there something else you think I should know to understand better your capital investment experience?

i. Is there anything you would like to ask me? 